\title{
The Psyche of Oppression
}

\author{
Sibonginkosi Mazibuko* \\ University of South Africa, South Africa
}

Submission: October 26, 2018; Published: December 03, 2018

*Corresponding author: Sibonginkosi Mazibuko, University of South Africa, Associate Professor and Chair of Department, South Africa

\section{Opinion}

The importance of the mind is critical in many ways. Even some diseases can be cured by addressing specific psychological issues. Similarly, in social settings, the mind determines the destinies of peoples and nations. In this opinion piece based on the forthcoming book Apartheid in South Africa: Reflections and Lessons edited by Francis Lukhele and published by Nova Publishers, and to which I contributed the chapter titled Unchain the Mind, I write about the significance of the mind in resisting oppression. This is important because without a hold on the minds of the oppressed, the oppressor cannot control their 'subjects'. This piece therefore is concerned with the objectives of the Status Campaign of 1959 during the colonial oppressive rule of the settler minority in South Africa. The campaign actually raptured the single narrative of inferiority and superiority of one race over the other.

The Status Campaign was a response to colonial and settlercolonial conditions under which African people were forced to live under. Those were conditions of violence and inhumane policies. Their dignity as a people was subjected to psychological oppression and subjugation among other things. However, to overthrow that unjust system required that those who were its victims rose to claim their birthrights as human beings. If they accepted or tolerated the denigrating treatment that their colonizers melted out to them, they could not demand freedom and self-determination.

Launching the Status Campaign, the founding President of the Pan Africanist Congress of Azania (South Africa), Robert Mangaliso Sobukwe (1924-1978), declared that for the people to be free, they first needed to free themselves psychologically and he explained that: "The struggle in South Africa hinges on the twin problem of land and status. And our immediate battle is for "STATUS", political, economic, social etc. And 1958 must be a STATUS YEAR....we are going to put a stop to the terms "Boys" and "Girls", which are so ungrammatically used by white South Africa... We will no longer have "Jack", "George", "Nancy", "Jane", etc. as handy labels to be attached to any black man or woman by any white man or white woman, white boy or white girl... It is an unfolding and expanding campaign, involving the political, economic and social status of the African It is our task to exorcise this slave mentality, and to impart to the African masses that sense of self-reliance which will make them prefer self-government to the good government... We are reminding our people that they are men and women, with children of their own and homes of their own ... we are reminding our people that acceptance of any indignity, any insult, any humiliation is acceptance of inferiority. The campaign will free the mind of the African and once the mind is free, the body will soon be free. Once white supremacy has become mentally untenable to our people, it will become physically untenable too, and will go ..." [1].

Sobukwe targeted the day-to-day suffering of the African people in the hands of white people who regarded Africans as children regardless of their ages, or mental capabilities. In South Africa, it was 'normal' for the white people to refer to their African employees as boys and girls, or even give them names other than those Africans considered theirs. White children also grew up with that mentality and came to expect unquestioned obedience from the African peoples. Sobukwe explained that as long as African people in their big numbers 'accepted' insults such as being called boys and girls by whites, and even by white children, they would not be able to rise against the system of white supremacy. It was therefore critical that the African psyche be reoriented in the desired direction in preparation not only for the final liberation, but also for the execution of the process of liberation itself.

Pheko [2] posits that the PAC launched the Status Campaign as a first step towards liberation from colonialism, which it had identified as a national problem in South Africa. It argued that the oppressive laws would disappear with the overthrow of the settler-colonial State. Sobukwe therefore very early identified the land question as fundamental in the liberation of African people. It argued that the suffering of Africans had come as a result of their defeat by the colonizing foreign minority and the resultant loss of land. To that effect, the return of land was the crucial condition that would restore the dignity of the African. However, the oppressed could never rise against their oppressors until they were mentally ready to do so. Such readiness meant rejection of white rule and the humiliating treatment, which Africans were being subjected to. The Status Campaign therefore recognized the importance of psychological warfare required for liberation. 
Pheko has argued that the Status Campaign was a process of undergoing mental revolution and mind decolonization. In the words of Fanon (1963, 1 \& 266) mind decolonization should be "unconditional, absolute, total and seamless". In South Africa, this was necessary because the settler-colonial State had inculcated a psychology of African inferiority and supremacy of the Caucasian (white) race something Sobukwe also disputed arguing that there is only one race-humans. He argued that when it comes to human beings, 'race' has no plural. The colonialists had devised means to infuse the fallacy of white supremacy through many channels including the newspapers, books, music, arts, radio and films. The Status Campaign culminated into the Sharpeville Massacre on 21 March 1960 as African people took to resisting the pass laws, which restricted their movement in South Africa.

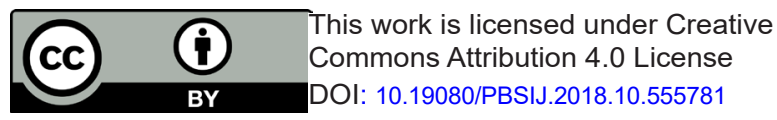

I am thinking that Sobukwe had carefully studied the modus operandi of the settler-colonial administration in South Africa and recognised that the mind was central in the whole situation. To continue the oppression, the oppressor relied on manipulating the mind of the oppressed. Similarly, Sobukwe understood that until the mind was free from the colonial grip, it would be impossible to liberate the oppressed. In this regard, the psychological makeup of individuals and groups is critical in understanding their conditions.

\section{References}

1. Karis T, Carter GM (eds) (1973) From protest to challenge: A documentary history of African politics in South Africa, 1882-1964. Hoover Institution Press Park, California, pp. 499.

2. Pheko SME (1994) The land is ours: The political legacy of Mangaliso Sobukwe. Pheko \& Associates: New York, p. 27-29.

\section{Your next submission with Juniper Publishers will reach you the below assets}

- Quality Editorial service

- Swift Peer Review

- Reprints availability

- E-prints Service

- Manuscript Podcast for convenient understanding

- Global attainment for your research

- Manuscript accessibility in different formats ( Pdf, E-pub, Full Text, Audio)

- Unceasing customer service

Track the below URL for one-step submission

https://juniperpublishers.com/online-submission.php 